\title{
THE FACTOR OF TIME IN HUMAN GEOGRAPHY
}

\author{
${ }^{1}$ Yaroslav OLIYNYK, ${ }^{2}$ Anatoliy STEPANENKO \\ 'Taras Shevchenko National University of Kyiv, Ukraine \\ 2State Institution "Institute of Environmental Economics and Sustainable Development of National Academy of Sciences of Ukraine" \\ 'oliynik_ya@univ.kiev.ua
}

\begin{abstract}
The article discusses the nature of social time, a form of existence of society, which manifests itself in successive events, and consists of social and individual perceptions. Human geography studies social characteristic of the time in historical and spatial context, and analyzes its territorial dimension. Each historical epoch has a peculiar perception of time. Time does not exist by itself; it is always associated with the phenomena and processes occurring in the surrounding world. However, time is a physical factor which has properties that allow participating actively in all natural processes, providing the causal connection of phenomena. In society the time appears in the form of activity. Thus, the time expresses also the quantitative side of being, i.e. the content of the social process. Sensation, perception and experience of time in some way are influence by natural factors, such as geographical environment. The main properties of time are duration, irreversibility, one-dimensionality, direction, speed of time and flow of time. The peculiarities of social time include heterogeneity, diversity, and temporality. Historical geography has a large importance in the study of time.
\end{abstract}

Key words: time, social time, spatial time, historical geography, properties of time, liminality.

UDC: 911.3

\section{ФАКТОР ЧАСУ В СУСПІЛЬНІЙ ГЕОГРАФІї}

\author{
'Ярослав ОЛІЙНИК, ${ }^{2}$ Анатолій СТЕПАНЕНКО
}

'Київський начіональний університет імені Тараса Шевченка, Україна

${ }^{2}$ Державна установа «Інститут економіки природокористування та сталого розвитку Національної академії наук України» 'oliynik_ya@univ.kiev.ua

Анотація: У статті розкривається сутність поняття соціальний час - форми буття соціуму, яка виявляється в зміні послідовних подій та складається з соціальних й індивідуальних уявлень. Соціальна географія дає характеристику соціального часу в історико-просторовому контексті та аналізує його в територіальному вимірі. Для кожної історичної епохи властиве особливе сприйняття часу. Час не існує сам по собі, він завжди пов'язаний з явищами і процесами, що відбуваються в оточуючому світі. Разом з тим, час - фізичний фактор, який має властивості, що дозволяють активно брати участь у всіх природних процесах, що забезпечують причинно-наслідковий зв'язок явищ. У суспільстві час виступає у формі діяльності. Таким чином, час виражає і кількісну сторону буття, тобто зміст соціального процесу. На відчуття, сприйняття і переживання часу певним чином впливають і природні чинники, і географічне середовище. До основних властивостей часу відносяться тривалість, незворотність, одномірність, темп часу, спрямованість, перебіг. До особливостей соціального часу відносять його неоднорідність, багатоплановість, темпоральність. У вивченні часу вагоме значення належить такій науці, як історична географія.

Ключові слова: час, соціальний час, просторовий час, історична географія, властивості часу, лімінальність.

удк: 911.3

Еволюція поняття категорії час. Соціальний час - нерозривно пов'язаний з соціальним простором процес руху, розвитку соціальних систем та ї відбиття в людській свідомості. Це форма буття

(C) Я. Олійник, А. Степаненко соціуму, яка виявляється в зміні послідовних подій та складається 3 соціальних й індивідуальних уявлень. Як природні (фізика, біологія, медицина), так і суспільні (політекономія, економічна і соціальна географія, історія, соціологія тощо) науки вивчають час, але кожна 3 них розглядає його під своїм 
кутом зору. Що стосується соціальної географії, то вона дає характеристику соціального часу в історико-просторовому контексті, аналізує його в територіальному вимірі.

У колишньому радянському суспільстві термін «соціальний час» появився в 60-ті роки ХХ ст. Він наповнювався специфічним соціальним змістом тими подіями і процесами, які пов'язані з діяльністю людини, колективу, суспільства. Будь-яка структура або внутрішня організація систем існує в тому числі і як часова структура. Вона визначається характером діяльності людей. Ключем до вивчення структури соціального часу $\epsilon$ дослідження структури видів діяльності в суспільстві. Такий підхід розвивається у вивченні бюджетів і балансів часу.

Соціальна філософія вивчає суспільство, що розвивається в часі, діяльність суб'єктів історії, соціальні процеси й феномени в їхньому взаємозв'язку й розвитку. Тому дуже важливо з'ясувати, як усвідомлюється людьми час, яку роль він відіграє в житті соціуму. У нашу динамічну епоху слово «час» по частоті вживання займає одне $з$ перших місць. Ми постійно поспішаємо, нам бракує часу для рішення багатьох повсякденних завдань. Ми враховуємо навіть не добу, а години, хвилини й секунди.

Люди давно почали усвідомлювати час, але в кожну історичну епоху він сприймався по-різному. Сучасне сприйняття часу дуже сильно відрізняється від його сприйняття людьми давнього світу й навіть Середньовіччя. Справа в тому, що уявлення про час, відчуття його й необоротності пов'язані з поняттям становлення й розвитку, але люди не завжди могли зрозуміти й усвідомити, що все у світі формується, змінюється й розвивається. Первісні племена, наприклад, сприймали світ як щось раз і назавжди дане й незмінне. Природно, що їхнє розуміння часу носило примітивний характер. Вони представляли час лише як кінець життя й не надавали йому соціального значення. Люди не цінували час у тому розумінні, що не фіксували його як певний етап їхьої життєдіяльності. Навіть дотепер, як пише французький історик Ф. Арiєс, в африканських джунглях поняття про вік життя усе ще досить смутне. Це тим більше стосується первісних суспільств. Саме сприйняття часу зв'язувалося $з$ подіями, що мали місце в житті роду або плем'я. Наприклад, день народження дитини запам'ятовувався у зв’язку з якою-небудь подією: або із днем народження першої дитини, або із удалим полюванням тощо. Але дата народження, звичайно, не фіксувалася. Таке відношення до часу, природно, пояснюється низьким рівнем суспільних відносин, культури й відсутністю писемності. Об'єктивно не було необхідності в точній фіксації часу, у його розподілі на години, хвилини, секунди. Примітивному соціальному життю відповідало примітивне сприйняття часу [11].

В античному світі уявлення про час різко міняється. Час уже одержує соціальну характеристику як фактор, що грає важливу роль у життєдіяльності людини, й тому потребує до себе дбайливого відношення. Люди починають усвідомлювати зв'язок сьогодення, минулого й майбутнього. Так,
Аристотель писав, що «сьогодення час стикається 3 минулим і майбутнім».

Оскільки рабовласницьке суспільство перебувало на більше високому рівні розвитку, чим первісне, сприйняття часу вже має не просто чутливоосязаємий характер (зв'язок часу 3 якою-небудь подією), але й абстрактний, тобто час оцінюється незалежно від конкретних речей, подій і явищ.

Однак справжнє розуміння часу починається 3 епохи Відродження. Це - епоха, що починається iз другої половини XVстоліття. Королівська влада, опираючись на городян, зломила міць феодального дворянства й створила великі, по суті, засновані на національності, монархії, у яких почали розвиватися сучасні європейські нації й сучасне буржуазне суспільство. Епоха відродження - це епоха розкладання феодалізму й формування капіталістичних суспільних відносин. Капіталіст проявляє незвичайну активність для одержання більшого прибутку, i тому він береже кожну годину, кожну хвилину, тому що розуміє, що від економії часу залежить його багатство. Сонне Середньовіччя було розбуджене активно діючим буржуа. От чому синонімом часу стала практична діяльність, їі ритм. Саме 3 Відродження 3'являється можливість порівнювати одну історичну епоху 3 іншою через призм часу. Із цього періоду люди почали представляти свою історію, як історію, що розвивається в часі.

Відомий французький історик Ф. Бродель, який зробив революцію в історичній науці своєю пропозицією враховувати економічні і географічні фактори при аналізі історичного процесу, пише, що соціальний час представляє складне й суперечливе явище, що містить у собі минуле й сьогодення людства [4].

Цікаво відзначити, що Бродель критикує тих істориків (наприклад, Лакомба), які заперечували об’єктивний характер часу. Не можна, пише він, абстрагуватися від часу й вважати його своєю суб'єктивною ідеєю, тому що час - це процес створення матеріальних багатств, життєдіяльності людини. Усяка подія пронизана часом, тому що воно пов'язане з іншими подіями, які мали місце раніше.

У соціальній філософії час розглядається в більше широкому, філософському змісті. Весь історичний процес вивчається як процес, що відбувається в часі, детермінований матеріальними відносинами. При цьому соціальна філософія опирається на досягнення інших наук, зокрема політичної економії, географії, соціології, історії. Філософський аналіз часу вимагає знань конкретної дійсності, що можливо тільки при врахуванні досягнень інших наук. Візьмемо історичний час. Ним займається не тільки історична наука, але й соціальна філософія. Вона досліджує його онтологічні й гносеологічні характеристики. В онтологічному змісті соціальний час виникає разом 3 історією суспільства. Будучи його формою існування, він розвивається й змінюється разом 3 ним. Під гносеологічним аспектом мається на увазі усвідомлення часу в міфологічних, натуралістичних і космічних термінах. Інакше кажучи, у цьому випадку 
мова йде про неісторичне сприйняття часу, коли він не зв'язувався 3 історичним розвитком суспільства. У міфах, казках, епосі час не розвивається й не змінюється. Але в міру розвитку історичного процесу гносеологічне фарбування часу теж міняється. Він вже сприймається не через міфи й казки, а через історичні події й факти.

М.А.Барг спеціально виділяє календарний час, що на відміну від історичного часу тече рівномірно, ритмічно й безупинно. Він однаковий для всіх епох і періодів. Так, календарний час у первісному суспільстві протікав також ритмічно й рівномірно, як протікає в нашу епоху, хоча ритм родового ладу істотно відрізняється від ритму сучасних людей. Календарний час підкоряється своїм власним законам, і він незалежний від розвитку й зміни історичних подій.

На відміну від календарного часу історичний час припускає змістовний аналіз людської історії. Він насичений конкретним соціально-історичним змістом i, по справедливому зауваженню японського філософа Я. Кєндзюро, пронизує всю історію, оскільки аналіз часу дозволяє представити людське суспільство як соціальний організм, що перебуває в постійному розвитку. Ми почуваємо історичний час завдяки ходу історії, подій, явищ, процесів. Ігнорування часу неминуче веде до неісторичного підходу до дослідження суспільних відносин.

Порівнюючи календарний та історичний час, не можна не відзначити й те, що якщо календарний час завжди тече рівно, плавно й ритмічно, то історичний час переривчасто й відносно. У ньому можливі й циклічність, і повторюваність (зрозуміло, не абсолютна), і навіть рух назад. Це видно особливо тоді, коли відбуваються великі події, що роблять великий вплив на наступний суспільний розвиток.

Історичний час пов'язаний зі змістовним аналізом соціальних організмів і тому вимагає цілісного підходу. Він здобуває зміст лише за умови, якщо його визначати як специфічну форму існування соціальної цілісності. Аналіз змісту історичного часу можливий тільки при врахуванні діалектичної єдності всіх фактів, явищ, процесів і подій історії, тому що вони й становлять його зміст. I для розкриття циклічності й переривчастості історичного часу потрібно досліджувати його зміст, тобто події й процеси, що мали місце на даному відрізку часу. Насиченість історичного часу залежить від змістовності й насиченості історичних подій. Прикладом можуть служити революції й війни, які ламають звичний уклад життя людей і за короткий період якісно змінюють громадські порядки, менталітет і спосіб життя людей.

Календарний час не залежить від людей, тоді як історичний час залежить від них, і в цьому змісті він (iсторичний час) суб'єктивний. Його зміст залежить від діяльності суб'єктів історії, які можуть швидко наповнити його більшими історичними подіями, що мають величезне значення для людства, і день у день трудитися, створювати матеріальні й духовні цінності й передавати їх з покоління в покоління.

Час як основна умова всякого розвитку розкриває закономірності взаємодії суспільства i природи, дає уявлення про те, як людське суспільство в міру просування по шляху соціального процесу вдосконалюється, гармонізується й перетворюється в дійсний простір людей, унікальних творців цивілізацій на Землі.

Історична географія як наука про різні аспекти взаємовідношення населення i природи в минулі історичні періоди отримала широкий розвиток. Різноманіття аспектів дослідження взаємовідношення природи і суспільства, що історично склалися, привело сучасних зарубіжних учених до надзвичайно широкого тлумачення завдань історичної географії. Англійський історик-географ С. Т. Сміт виділяє 3 напрями в сучасній історичній географії Англії і США: 1) вивчення історії змін ландшафту під впливом людини на природу; 2) історична географія як наука, що реконструює географію минулого; 3) дослідження географічних змін у часі [12].

Глава Берклійської школи історико-географів К. Зауер (Каліфорнія, США) вважає, що завданням географії $\epsilon$ вивчення взаємозалежності всіх живих істот на землі, причому людина в цій взаємозалежності грає провідну роль. Реконструкція природних умов минулого необхідна для пояснення сучасного розповсюдження людей на землі, аналізу сучасної господарської освоєності.

Принципова відмінність в об'єктах дослідження історичної фізичної географії і історичної соціальноекономічної географії викликає необхідність застосування різної методології дослідження. Проте при всій відмінності об'єктів (фізико-географічних, економіко-географічних) залишиться загальний підхід до їх вивчення: i соціально-економічна, i фізична географія сучасності зацікавлені в дослідженні історичного процесу формування сучасних географічних об'єктів. Історико-генетичний підхід особливо важливий для цілей географічного прогнозу, значення якого важко переоцінити. Таким чином, одному 3 головних завдань географічного напряму в історичній географії $\epsilon$ підготовка необхідного матеріалу для цілей географічного прогнозу.

Історична географія вивчає зміни в географічній оболонці Землі як в силу природніх причин, так і під дією людини. В ній використовуються різні методи:

- історичні (вивчення архівних джерел, пам'ятників матеріальної культури і тому подібне);

- географічні (картографування, районування, ландшафтний підхід, польове вивчення реліктів, дендрохронологія і інше);

- суміжних наук (аерокосмічна індикація, математичне моделювання та інше).

Географія осьового часу. Термін, який запропонував німецький філософ, психолог Карл Ясперс, відображає добу якісних трансформацій соціокультурної системи при іiі переході від ранніх до розвинених цивілізацій. Тривав з 800 по 200 рік P.X.

Ясперс, наприклад, розглядає час в онтологічному аспекті. Він вводить поняття осьового часу 
у зв'язку з дослідженням осі світової історії, що, на його думку, «може бути виявлена тільки емпірично, як факт, значимий для всіх людей» незалежно від віросповідання. IIÏ треба шукати там, де з'явилися необхідні умови для формування сучасної людини. Ясперс вісь світової історії відносить в часі близько 500 років до н.е., коли відбулися якісні зміни в історії й з'явився сучасний тип людини.

Карл Ясперс пов'язував осьовий час 3 ідейносвітоглядними зрушеннями, що мали місце в центрах випереджаючого розвитку людства (Греція, Палестина, Іран, Індія та Китай) між VIII та III століттями до н.е. Тоді майже одночасно діяли такі «вчителі людства», як Піфагор, Сократ, Платон, Арістотель, Єремія, Заратустра, Гаутама Будда, Лао-Цзи, Конфуцій, які висунули персоналістичні цінності та постулювали кінцеву причетність кожної конкретної людини до трансцендентно-сакральної першооснови буття [2].

Осьовий час відповідав, за Карлом Ясперсом, переходу людства від першої, ранньокласової стадії розвитку суспільства, до другої, традиційної (становокласової), яка характеризується якісно вищим рівнем самосвідомості та можливостей самореалізації особи в різних сферах життєдіяльності за умов порушення однозначної кореляції між соціальним, політичним та економічним статусами індивіда.

Внаслідок бурхливих трансформацій у зазначених регіонах на середину першого тисячоліття до н.е. виникають антична (початково як давньогрецька), давньоєврейська (іудейська), давньоіранська (зороастрійська), давньоіндійська (індуїськобуддійська) та давньокитайська (конфуціанськодаоська) соціокультурні системи, з яких вийшли вищі релігії (буддизм, християнство, іслам, зороастризм, іудаїзм, джайнізм, індуїзм, даосизм і конфуціанство), що стали основою великих цивілізацій останніх двох тисячоліть.

Осьовий час, у його ясперсівському розумінні, варто зіставити з глобальними техніко-технологічногосподарськими змінами, що охопили смугу давніх цивілізацій від Еллади до Китаю між серединами II та I тисячоліть до н.е. Технологічний прогрес не зводився лише до поширення чорної металургії, а мав системний характер. Модернізація знарядь сільськогосподарської праці і ремісничого обладнання, верстатів не була прямим наслідком поширення заліза. На Близькому й Середньому Сході вона в більшості випадків навіть передувала йому, а в Середземномор'ї, Індії та Китаї проходила одночасно 3 масовим оволодінням залізоробною справою. Цей технологічний переворот в усіх давніх цивілізаціях завершується на середину першого тисячоліття до н.е. Принципова відповідність між зрушеннями в техніко-технологічній та релігійно-філософській сферах не була випадковими. У соціально-економічному плані феномен осьового часу пов'язаний із виникненням автономних щодо державних форм власності і становленням у провідних містах товарно-ринкових відносин, у суспільно-моральному - із визнанням за людиною права стати в опозицію до освяченого авторитетом предків і релігією світо- гляду або навіть виступити з відкритим засудженням можновладців, як пророки Ізраїлю та Іудеї.

3 осьовим часом пов'язані процеси створення світових імперій. Першими прообразами пізніших імперських структур осьового часу були держави Саргана Аккадського та III династії Ура у Дворіччі, давньоєгипетське Нове царство. Безперервна лінія імперського розвитку розпочинається 3 часу оволодіння чорною металургією і початком масового виробництва якісної зброї, наприклад на Близькому Сході цей процес у VI сторіччі до н.е. завершився утворенням перської імперії Ахеменідів, пізніше подібні імперії виникають в Індії та Китаї. 3 цього часу імперська структура стає в більшості цивілізованих регіонів нормою стабільного життя.

Духовно-культурні зрушення осьового часу, як і утворення великих і відносно стабільних держав імперського типу зі строкатим у культурно-мовному плані населенням, істотно позначилися на етнічному процесі, бо в межах великих держав відбулися змішання, культурна синкретизація та мовна нівеляція людей, різних за етнічним походженням. Соціально-політичні та релігійно-культурні фактори сприяли розмиванню етнічних бар'єрів i переоформлення етнічної свідомості. Поняття підданства та релігійної належності набувають більшої ваги, ніж етнічне і родове походження. Люди насамперед ідентифікують себе 3 політичними та конфесійними реаліями, із причетністю до певного соціального стану, що в деяких випадках (касти в Індіiі) стає найістотнішим. Макроетнічні спільності складаються на основі макрополітичної та конфесійної єдності. Периферійні відносно найпросунутіших регіональних цивілізацій етноси долали межу ранньокласовим та станово-класовим суспільствами за наявності імпульсів із боку розвинутіших сусідів, так що за деяких обставин доба ранньокласових відносин минала впродовж двох-трьох століть. Загальна тенденція полягала в тому, що не повністю розвинуті ранньокласові структури прискореними темпами трансформувалися в традиційні (станово-класові), а вищі релігії накладалися на варварські духовно-культурні форми, синтезуючись із ними. Подібне, зокрема, мало місце й у вітчизняній історії перших століть Київської Русі.

Планетарний час. Астрономічний (календарний) час, тобто час, природними референтами якого $€$ рух Землі відносно інших космічних об'єктів, не $є$ єдиним поняттям часу. Так його властивості гомогенність, безкінечна ділимість і неперервність - не є обов'язковими для інших часів (економічного, соціального, психологічного тощо). Темпоральні відносини в суспільстві неадекватно відбиваються в одиницях та інтервалах астрономічного часу. У соціології свій час, який виражає зміни або рухи соціальних феноменів у термінах інших соціальних феноменів, взятих як початок підрахунку. Ті або інші календарні фази означають для нас щось більше тоді, коли вони перетворені в соціальний час. В основі будь-яких календарних систем числення часу знаходиться соціальна діяльність і спосіб життя групи, одноманітні та регулярні коливання i 
пульсації колективної поведінки. у високодиференційованому суспільстві множина локальних систем часу не справляються з виконанням ролі координації спільної діяльності багатьох змін на значному географічному просторі. Тому виникає необхідність у введенні максимально розширеної і стандартизованої системи часу. В глобальному масштабі ця роль була відведена системі часу, заснованої на астрономічних референтах.

В кін. I - поч. II ст. н.е. Мартін Тірский запропонував розбити земну кулю на паралелі i меридіани (мережа). Так отримали 90 паралельних кругів, проведених 3 півночі від екватора i 90 до півдня від нього - північна і південна широта - i дуг-меридіанів. У 1844 р. за нульовий був прийнятий меридіан міста Грінвіча. В результаті з'явився всесвітній час, як середній час першого часового поясу, названого середньоєвропейським, $180^{\circ}$ на схід від Гринвічу і $180^{\circ}$ на захід від нього відкладають східну і західну довготу. Таким чином, положення будь-якого об'єкту визначається довготою і широтою, виражених в градусах, хвилинах i секундах. Всесвітній час $є$ середній сонячний, сонячний час початкового меридіану. Останній існує умовно, так вирішила людина.

У підсумку маємо різноманіття поясного часу. Практична життєдіяльність людини породила задачу отримання, зберігання i передачі точного часу. Точний час отримують 3 допомогою спостереження за сонцем i зірками. Шляхом спостереження за декількома зірками можна отримати моменти точного часу 3 погрішністю біля $1 / 10^{9}$ с [5].

Подальші дослідження по збільшенню точності і стабільності при вимірі часу пішли по шляху джерел коливання - атомів і молекул. Так, були створені молекулярні аміачні годинники, атомно-променеві цезієві годинники з квантовим генератором та ін., що дозволило вирішити нові задачі космічної навігації, руху Земної кори, руху материків.

Тривалість життя людей вимірюється роками, тобто порівнюється 3 обертанням Землі навколо Сонця, в процесі якого видиме положення зірок кожну ніч зміщується, а Сонце переміщається по небокраю від однієї групи зірок до другої. На основі знань видимого світу і зародилися знаки зодіаку. Відзначимо, що природною мірою проміжків часу, більш коротких, ніж рік, є доба (обертання Землі навколо своєї осі).

Океанічні припливи сповільнюють обертання Землі, а атмосферні прискорюють. Атмосферні припливи полягають в тому, що Сонце, впливаючи на атмосферу, викликає зміни барометричного типу. При обертанні Землі за добу зони зміни часу обходять навколо всієї Земної кулі. Над кожною точкою Землі максимум тиску атмосфери наступає на дві години раніше проходження через меридіан Сонця або антисонця, тому вони (атмосферні припливи) i прискорюють обертання Землі. В даний час океанічний сповільнюючий момент сил переважає прискорюючий атмосферний, так що обертання Землі сповільнюється.

Фізичний еталон часу - астрономічні атомно- променеві цезієві часи. У 1964 р. був створений Міжнародний комітет мір і ваги. У 1967 р. обрахували тривалість секунди. Вона рівна 9192631770 періодам випромінювання, відповідного переходу між двома надточними рівнями, основними станами атома цезію-133. Такий годинник має високі точність i відтворюваність. Пізніше появився водневий стандарт частоти і часу.

Фізіологічні функції залежать від біологічних годинників живої матерії. На жаль, соціальна еволюція огородила людину від використання власних біологічних годинників. Але оточуючі людину рослини в природних умовах старого часу відкривають і закривають пелюстки своїх квітів: зранку - мак, шипшина, цикорій, мати-й-мачуха; ввечері - $є$ духмяний тютюн, нічна фіалка тощо. Що $\epsilon$ внутрішнім годинником живих організмів, до цих пір не установлено. 3 приводу механізму біологічних годинників існують різні молекулярні гіпотези. Одна - білкова, пов'язана із скручуванням і розкручуванням в певному ритмі білкових молекул. Друга - ДНК діють як первинний маятник біологічних годинників. Послідовність реакції білкового синтезу виконують роль ритмів, механізм відрахування часу. Також є думка, що біологічний годинник регулюють космічні випромінювання, магнітне поле Землі і сам рух в космічному просторі Сонця, Землі і Місяця. Сезонні часу включають i виключають роботу окремих генів (спання тварин).

Біологічний годинник дуже важливий для життя людини. Відомо, що людина знаходиться у владі добових ритмів (більше 40 фізіологічних процесів людини залежать від біологічних годинників). Вважається, що розвитком організмів та їх формуванням управляє тріада: генетична програма, організаційний центр та інформаційне поле. Але до цієї тріади необхідно включити час, який є не просто тривалістю від однієї події до іншої, вимірюваною годинами, а являє собою фізичний фактор, який має властивості, що дозволяють активно брати участь у всіх природних процесах, забезпечуючи причиннопослідовний зв'язок явищ [5].

Просторовий час. У процесі дослідження розвитку нестаціонарних і відкритих дисипативних структур неможливо обмежитися уявленням про час, як про чисто кількісну характеристику процесів. У зазначених системах мають місце стадії нестійкості, режими із загостренням, у ході яких відбуваються якісні зміни. Через це в енергетиці враховується не тільки вплив більш ранніх стадій на наступні, минулого на сучасне, але й майбутнього на сучасне. Необхідність характеризувати час не тільки кількісно, але i якісно обумовлюється моделями тих просторових і часових відносин у структурах, що самоорганізуються, котрі досліджуються синергетикою.

Німецький філософ M. Хайдеггер подолав традиційне розуміння часу як «обрію безкінечного в обидва боки» [9, с. 45].

Думку про множинність часів розвиває I. Валлерстайн, стверджуючи, що кожному різновиду соціального часу відповідає різновид соціального 
простору. Так можна говорити про соціальні часи (TimeSpaces) [14]. Валлерстайн, розглядаючи броделівські часи - епізодичний час, циклічний час, структурний час та час мудріїв (це час довгостроковий або, надто довгостроковий i Бродель сказав про нього, що якщо він існує, то він може бути тільки часом мудреців), стверджує, що кожен із цих часів має свій простір, i їх можна поєднати однією категорією «час-простір». Для визначення простору він звертається до тих сутнісних об'єктів, що обмежуються цим часом, i, таким чином, знаходить просторові аналоги категоріям соціального часу [14].

Час не існує сам по собі, він завжди пов'язаний 3 явищами і процесами, що відбуваються в оточуючому світі. Разом з тим, час - фізичний фактор, який має властивості, що дозволяють активно брати участь у всіх природних процесах, забезпечуючи причиннонаслідковий зв'язок явищ.

У суспільстві час виступає у формі діяльності. Це тривалість події, обсяг часу для створення предметів, час життя. Таким чином, час виражає i кількісну сторону буття, тобто зміст соціального процесу (сповільнення, прискорення, підвищення, падіння, регрес, прогрес). У суспільстві завжди існує не якийсь монолітний час, а спектр соціальних ритмів, чергувань, розмірності, обумовлених природою окремих соціальних спільностей.

На відчуття, сприйняття і переживання часу певним чином впливають і природні чинники, i географічне середовище. Залежно від тривалості дня і ночі, зими і літа люди по-різному «живуть у часі». У жителів екваторіальної зони інша ритміка часу, аніж у ескімосів або тих, хто мешкає в зонах з полярним кліматом.

Для соціології важливий облік і «календарність», тобто поступальність соціальних подій, і «сумативної сукупності» часу в соціальних суб'єктів - індивіда, спільності, групи, колективу, асоціації. Так, у первісному суспільстві переважає вільний час ,він розподіляється більш-менш рівномірно серед усіх членів суспільства. Нерівність тут має суто антропологічні (головним чином природні) виміри. Вільний час розподіляється на користь дітей або людей похилого віку. У буржуазному суспільстві, навпаки, необхідний час (час виробництва, обміну, розподілу і споживання) переважає над вільним. Розподіл вільного часу тут ведеться вже за соціальноекономічними і політичними ознаками (багатство, влада, престиж).

Соціологи оперують такими категоріями, як сумативний фонд часу, «маса часу», «ресурс часу», «бюджет і баланс часу». Але це не що інше, як єдність часу в його календарному і об'ємному виразі. Фігурально виражаючись, динамізм означає швидше і краще, консерватизм, гальмування - сповільнення і гірше.

Отже, соціальний час - жива форма діяльності - виступає і як календарний час, і як сукупний час індивіда, соціальної спільності, суспільства в цілому, і як функція, умова і міра соціальних дій.

Ряд дослідників часу I. Пригожин, А. Біч та ін. вважають, що час існує завжди і скрізь (а не виникає), тобто завжди існує в непроявленому вигляді в будьякій матеріальній системі внаслідок будь-якого руху матерії [3, с. $19-20 ; 10$, с. 46-57].

Основними функціями соціального часу $є$ : взаємна синхронізація, координація і часова послідовність (sequential timing) окремих феноменів; організація часової системи для реалізації соціокультурної безперервності і для орієнтації в безкінечному потоці часу; осмислення пульсації соціокультурних систем і в той же час полегшення цієї пульсації або ритмів.

Властивості часу. До основних властивостей часу відносяться:

1. Тривалість - виступає як послідовність моментів, що змінюють один одного або станів, виникнення за кожним даним інтервалом часу наступних. Ніякий процес у природі не може відбуватися відразу, миттєво, він обов'язково триває в часі, що обумовлено кінцевою швидкістю поширення взаємодій і зміною станів.

2. Незворотність, що означає односпрямовану зміну від минулого до майбутнього. Минуле породжує сьогодення й майбутнє, переходить у нього. До минулого відносяться всі ті події, які вже здійснилися і перетворилися в наступні. Майбутні події-це ті, які виникають зі справжніх і безпосередньо попередніх їм подій. Сьогодення охоплює всі ті об’єкти, системи й процеси, які реально існують і здатні до взаємодії між собою. Взаємодія можлива лише при одночаснім співіснуванні об’єктів. Об’єкти, що співіснували в минулому, але перейшли в інші наступні стани матерії, уже недоступні ніякому впливу. На минуле фізично впливати неможливо, можна тільки змінити уявлення про минуле у свідомості реально існуючих людей. На віддалене майбутнє також не можна впливати, поки воно не виникне, оскільки реально воно ще не існує. Впливати можна на події сьогодення й на ті найближчі події майбутнього, які 3 них безпосередньо випливають.

3. Одномірність, що проявляється в лінійній послідовності подій, генетично зв'язаних між собою. Якщо для визначення положення тіла в просторі необхідно задати три координати, то для визначення часу досить однієї. Якби час мав не одне, а два, три й більше вимірів, то це означало б, що паралельно нашому світу існують аналогічні й ніяк не пов'язані 3 ним світи-двійники, у яких ті ж самі події розверталися б в однаковій послідовності.

4. Темп часу - це показник часу, що характеризує частоту зміни подій в системі. Цей показник характеризує сповільнення або прискорення часу. Темп часу та інтервал пов'язані між собою обернено пропорціональною залежністю: чим більше темп часу (чим швидше в системі проходить зміна подій), тим менше інтервал часу між певними подіями (певними моментами часу).

5. Спрямованість часу. Ще Лейбніц довів, що відмінність причин від наслідків рівносильна відмінності минулого від майбутнього. А оскільки причина передує наслідку, час спрямований від причини до наслідку й тому не можна поміняти причину й слідство місцями. Направленість 
(однонаправленість) - це послідовність передування подій (тривалостей) мінливого світу, але це також - сприйняття людиною руху часу в направленні через теперішнє в майбутнє. Напрям часу дає стріла часу, яка являє собою концепцію, що описує час, як пряму (тобто математично одновимірний об’єкт), простягнуту з минулого в майбутнє. 3 будь-яких двох незбіжних точок (осі часу) одна завжди $є$ майбутнім щодо іншої. «Стрілу часу» в науковий обхід ввів у 1927 р. британський астроном А. Еддінгтон. Як історична, так і термодинамічна стріла часу характеризують процеси, які ідуть в одному напрямі, вони визначають події, які не можуть бути змінені, які неможливо повернути у висхідний стан.

6. Перебіг часу - це перехід подій далекого майбутнього в події більш близького майбутнього, подій найближчого майбутнього в події сьогодення, подій сьогодення - у події близького минулого, подій минулого - у ще більш далеке минуле.

Деякі автори пропонують тріоду рівнів соціального часу: час історії суспільства (макрочас), час покоління і час індивіда (мікрочас). Макрочас непереривний і незворотній. Мікрочас дискретний, кінечний людських життів i оборотних хвиль поколінь. Життя індивіда незворотне. Але в широкому контексті незворотність часу індивіда знімається зворотністю часу поколінь через механізм спадкоємності і соціальної пам'яті, протікаючими в «зворотному часі» інституціональними практиками [1].

До особливостей соціального часу відносять його неоднорідність, оскільки він здатний стискатися, ущільнюватися в періоди революцій і катастроф i розтягуватися в період стагнації; він маркований критичними датами і завжди наповнений особливими соціальними життями. Багатоплановість соціального часу обумовлюється тим, що соціальні процеси різного рівня, масштабу і складності, кожний у своєму часовому інтервалі, із своєю послідовністю, ритмом і темпами, узгоджуються в єдиному ансамблі суспільного порядку і єдиним часом.

Неоднорідність соціального часу дає нам часову структуру: багатоплановість - часову координацію. Соціальний час не єдиний (багатомірний), що обумовлюється множиною відмінних одна від одної «локальних систем часу». Кожна локальна система відтворює ритми діяльності певної групи.

Соціальний час не є неперервним, оскільки він не може адекватно відбиватися єдиною цілісною шкалою, тому що різні інтервали часу в різному соціальному контексті наділяються різними значеннями (соціальними якостями), від природи та інтенсивності яких залежать часові зміни.

Референтом соціального часу визначають соціальну діяльність - де є людська діяльність, там є плин соціального часу. Тривалість того чи іншого процесу не $\epsilon$ визначальним фактором у визначенні соціального часу - важливо знати фазу і направленість коливань процесу з точки зору його функцій і організації соціальних часів.

В структурі соціального часу важлива роль належить темпоральності (від нім. temporalitat часовість знання, часові особливості), що являє собою часову сутність явища, породжену динамікою його особливого руху, на відміну від тих часових характеристик, які визначаються відношенням руху даного явища до історичних, астрономічних, фізичних та інших часових координат, взаємозв'язок моментів часу. В феноменологічно орієнтованій соціології, а також у психології та культурології, поняття темпоральності широко використовується для описання таких динамічних об'єктів, як особистість, соціальна група, клас, суспільство.

Перехід від одного стану в інший, коли система втрачає риси цілісності, є особливо важким у динаміці системи. Для цієї стадії характерні процеси деструктивності i хаотизації, які можна охарактеризувати як мінімальні. В цьому питанні актуальними і змістовними можуть бути результати i висновки дослідження в галузі культурної антропології, здійснені А.Геннеп і В.Тернер [6; 13]. Досліджуючи мінімальну фазу ритуалів приходу, тобто ритуалів зміни статусу (вільного, соціального тощо), в традиційних суспільствах вони дійшли висновку щодо структурованості фази переходу, що включає в себе три стадії:

- відокремлення - вибір та ізоляція індивіда від повної соціальної цілісності, позбавлення індивіда статусних характеристик належності до цієї спільності;

- власне перехід - період певного перехідного стану або лімінальності;

- реагрегація - відтворення.

У розвитку соціальних систем ключовим моментом $є$ лімінальна стадія як феномен переходу соціально-культурної цілісності (особистості, групи, суспільства) в новий культурний стан. Лімінальність характеризує зміну соціального статусу, цінностей і норм, ідентичності і самосвідомості, осмислення і розуміння, свідомості і мовної практики [8, с. 17-25]. Феномен лімінальності розгортається в суспільстві, що трансформується, здійснює культурний або цивілізаційний перехід, коли глибокі і радикальні зміни торкаються практично усіх сфер життя: від економічних, політичних та адміністративних реформ до цінностей, норм, способів світобачення i світоставлення в цілому. Сама соціокультурна цілісність суспільства, що трансформується, постає як контекст соціальної лімінальності як до індивіда, так і до всякої спільноти як підсистеми.

\section{References:}

1. Âkovlev V.P. Social'noe vremâ [Social time]. Rostov-on-Don, 1980. (In Russian).

2. Âspers K. Smysl i naznačenie istorii [The Origin and Goal of History]. Moscow, 1994. (In Russian).

3. Bič A. M. Osnovy teorii vremeni: Zakonomernâ̂ èvolûciâ relâcionnoj koncepcii vremeni [Fundamentals of the 
theory of time: a Natural evolution of the relational concept of time]. Kyiv, 2005. (In Russian).

4. Brodel' F. Čas svitu [World time]. Kyiv, 1998. (In Ukrainian).

5. Burceva S.A. Globalizaciâ: geostatističeskij podhod [Globalization: a geostatistical approach]. Moscow, 2005. (In Russian).

6. Gennep A. van. Obrâdy perehoda: sistemnoe izučenie obrâdov [Rites of passage: systematic study of rites]. Moscow, 2002. (In Russian).

7. Golubec' M.A. Seredoviseseznavstvo (invajronmentologiâ) [Environmentology]. Lviv, 2010. (In Ukrainian).

8. Gorbunova L.S. Ponâttâ času ì prostoru v kontekstì sučasnih socìokul'turnih transformacì [The concept of time and space in the context of modern sociocultural transformations] Nova paradigma [The new paradigm], 2005, Vol. 41. (In Ukrainian).

9. Hajdegger M. Bytie i vremâ [Being and time]. Moscow, 1997. (In Russian).

10. Prigožin I. Filosofiâ nestabil'nosti [The philosophy of instability]. Voprosy filosofii [The problems of philosophy], 1991, N. 6. pp. 46-57. (In Russian).

11. Social'nij čas [Social time]. Access mode: http://all-filosof.ru/socialna-filosofija/38/549/socialne-chas (In Ukrainian).

12. Teoriâ. İstoriâ geografiï: predmet ì metod [Theory. The history of geography: subject and method]. Access mode: http: //studin.t.at/i. (In Ukrainian).

13. Turner V.W. The Ritual Prozess Structure and Anxi-Structure. Hasmondsworth, 1974, 278 p.

14. Vallerstajn I. Izobretenie real'nostej vremeni - prostranstva: k ponimaniû naših istoričeskih sistem [The invention of the time realities - time: towards understanding of our historical systems]. Vremâ mira. Al'manah [The time in the world. Almanac], Vol. 2: Struktury istorii [Patterns of history]. Novosibirsk: 2001. (In Russian). 